[Agr. Biol. Chem., Vol. 31, No. 6, p. 705 709 . 1967]

\title{
Influence of Dietary Condition on Muscle Protein Composition
}

\section{Part II. Dietary Effect on the Composition of Muscle Protein Fractions}

\author{
By Yoji Yamatani* and Makoto Kandatsu \\ Department of Agricultural Chemistry, Faculty of Agriculture, The University of Tokyo \\ Received February 27, 1967
}

\begin{abstract}
A quantitative fractionation method of muscle protein was presented. Muscles from the adult rats fed a normal, a tryptophan-free and a protein-free diets separately for 4 weeks were fractionated by this method. The effects on the composition of the muscle protein fractions were different between the tryptophan-free and the protein-free diets. The decreases of non-protein nitrogen and sarcoplasmic protein by both deficient diets were greater than that of total muscle nitrogen, whereas those of actin, myosin and stroma were smaller. This show's the presence of the different dietary effects on the constituent proteins of muscle.
\end{abstract}

\section{INTRODUCTION}

Several studies using radioisotope tracer on the metabolism of muscle proteins reveal a dynamic state of muscle proteins having the different turnover rates smaller than those of average body proteins $s^{1 \sim 51}$ and the different dietary effects on the turnover rates of muscle proteins. $^{6 \sim 91}$ The turnover rates of sarcoplasmic, myofibrillar and structural proteins decrease in this order. The turnover rates of muscle proteins generally falls at high-protein

* Present address: Department of Agriculture, Mie University. This reports is a part of the doctorate thesis of Y. Yamatani presented to the University of Tokyo.

1) L. E. Bidinost, J. Biol. Chem., 190, 423 (1951).

2) S. F. Velick, Biochim. et Biophys Acta, 20, 228 (1956).

3) B.S. Kasavina and A. Umanskaya, Biokhimiya, 23, 550 (1958).

4) G. B. Gerber et al, J. Biol. Chem., 235, 2653 (1962).

5) A. Neuberger, Arzeneimittel Forsch., 10, 390 (1960).

6) G. Solomon and H. Tarver, J. Biol. Chem., 195, 447 (1951).

7) S. Kanikova et al., Docrady Primener Radioactiu. Isotop. $v$. med., 259 (1953).

8) J.C. Drefus et al, Proc. First UNESCO Intern'l Conf. Sci. Res., 3, 386 (1958).

9) J.C. Drefus, J. Kruh, and G. Schapira, Biochiem. J., 75, 574 (1960). feeding and rises at low-protein feeding or at fasting. ${ }^{6 \sim 91}$

T. Addis et al. pointed out a large protein store in muscle by the observation that the protein loss from muscle of the adult rats at fasting for 7 days reached $60 \%$ of that from all body proteins, while that from liver occupied only $16 \% \%^{101}$ J. S. Garrow suggested a concentration of protein synthesis in the more essential organs at the expense of the less essential, such as muscle, from the observation of different effects on various body proteins by protein depletion of dog. ${ }^{11}$

Dietary influence on the composition of muscle protein was studied to investigate the role of muscle protein as a store of body protein. In the preceding paper, ${ }^{12)}$ the significant difference in the amino acid composition of the muscle fractions of rats fed with different diets was observed. This is considered to be a result from the different dietary effects on the metabolism of the con.

10) T. Addis, J. L. Poo and W. Lee, J. Biol. Chem., 115, 111 (1936).

11) J. S. Garrow, J. Clin. Invest., 38, 1241 (1959).

12) Y. Yamatani and M. Kandatsu, This Journal, 31, 700 (1967). 
stituent proteins of the muscle. In this report, dietary effect on the composition of the muscle protein fractions was studied using a quantitative fractionation method of muscle proteins.

\section{EXPERIMENTALS}

1. Animals and diets. Male rats of Wister strain, weighing about $340 \mathrm{~g}$ were used in all the experiments. They were housed in individual cages. After the normal feeding for 8 days, 12 rats were divided into three groups. Three kinds of tests diets were used, whose compositions are shown in Table I. They differed only in the nitrogenous component. Diet and water were all given ad libitum.

2. Preparation of muscle samples. After the rats had been given the test diet for 4 weeks, they were bled enough by cutting the carotid artery under anesthesia with ether. Then, the skin is rapidly incised behind the shoulders around the body and stripped off. After which all the skeletal muscles were removed for the muscle sample.

3. Fractionation of muscle proteins. The fractionation method of muscle proteins is shown in Fig. 1, generally following those of Hasselbach and Schneider ${ }^{13}$ ) and that of Robinson. ${ }^{14}$ ) Treatments are
TABle I. Compositions of DieT

Ingredient $\begin{gathered}\text { Normal } \\ \text { diet }\end{gathered} \begin{gathered}\text { Tryptophan- } \\ \text { free diet }\end{gathered}$ Protein-

$\begin{array}{lccc}\text { Starch } & 69.6 \% & 69.6 \% & 89.6 \% \\ \text { Casein } & 20 & 20 * & 0 \\ \text { Soy bean } & 5 & 5 & 5 \\ \text { Mineral mixture** } & 5 & 5 & 5 \\ \text { Vitamin mixture*** } & 0.4 & 0.4 & 0.4 \\ \text { Total } & 100 & 100 & 100 \\ \text { Nitrogen content } & 2.88 & 2.56 & 0.05\end{array}$

* Performic acid oxidized casein; $2.5 \%$ of DLmethionine and $0.2 \%$ of L-cystine ${ }^{15}$ ) were added.

** Philips-Halt salt 4.16)

*** Hundred grams of diet contains 100 I.U. of vitamin A, 80 I.U. of vitamin $\mathrm{D}, 0.4 \mathrm{mg}$ of vitamin $B_{1}, 0.6 \mathrm{mg}$ of vitamin $B_{2}, 4 \mathrm{mg}$ of nicotinic acid, 4 $\mathrm{mg}$ of calcium pantothenate, $0.2 \mathrm{mg}$ of folic acid, 0.4 $\mathrm{mg}$ of pyridoxine, $2.4 \gamma$ of vitamin $\mathrm{B}_{12}, 10 \mathrm{mg}$ of inositol, $10 \mathrm{mg}$ of $p$-amino benzoic acid, $100 \mathrm{mg}$ of choline, $0.02 \mathrm{mg}$ of biotin, $5 \mathrm{mg}$ of vitamin $\mathrm{E}$ acetate, $0.1 \mathrm{mg}$ of menadione and $0.4 \mathrm{mg}$ of $\alpha$-tocopherol.

done in a cold room. About $2 \mathrm{~g}$ of hind legs' muscle cut by scissors and ground in a morter was extracted mildly by shaking for 20 minutes in 10 volumes of pyrophosphate solution. After the supernatant fluid had been removed by centrifugation, the residue was extracted twice more in the same way. To the

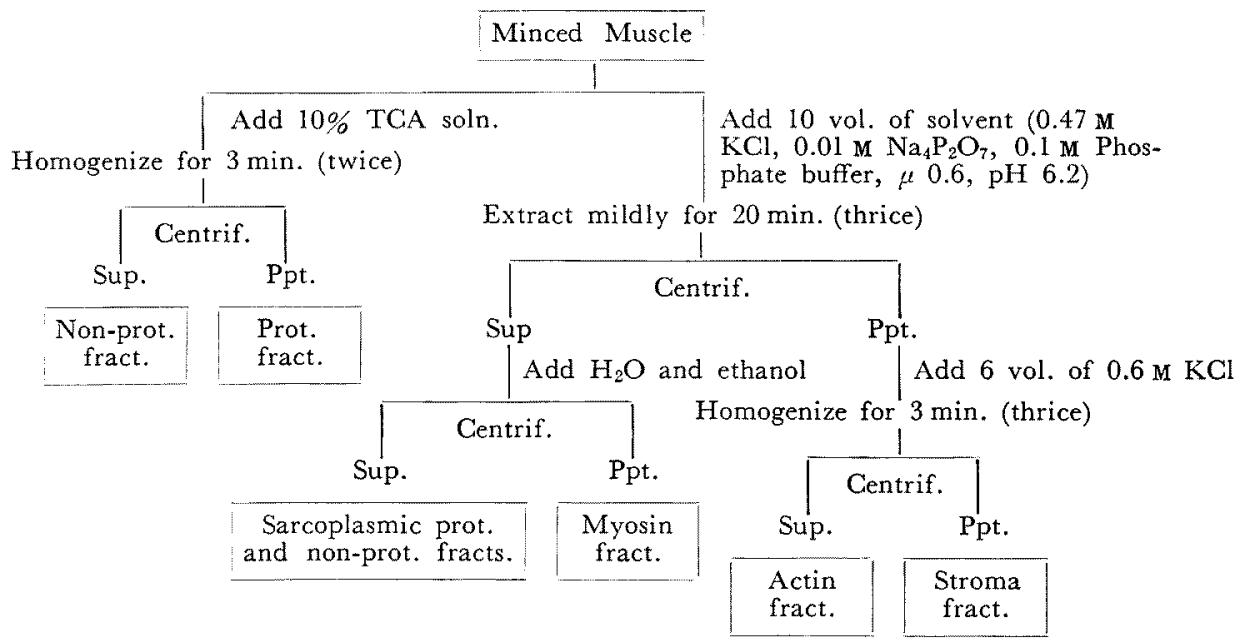

FIG. 1. Muscle Fractionation.

13) W. Hasselbach and G. Schneider, Biochem. Z., 321, 461 (1951).

14) D. S. Robinson, Biochem. J., 52, 621 (1952).
15) G. Toennies, J. Biol. Chem., 145, 667 (1942)

16) P. H. Phillips and E. B. Halt, ibid., 109, 657 
combined yellowish fluid were added water to attain the ionic strength of 0.1 and ethanol to $15 \%$. The mixture was left to stand overnight, the resulting white precipitation was collected by centrifugation for the myosin fraction and the supernatant fluid was kept for the sarcoplasmic protein and non-protein fractions. The insoluble residue was then homogenized in 6 volumes of $0.5 \mathrm{M} \mathrm{KCl}$ for 3 minutes. After removal of the supernatant by centrifugation, the residure was extracted twice in the same way. The insoluble residue corresponds to the stroma fraction and the resulting supernatant fluid to the actin fraction. Another sample of the minced muscle was homogenized in 10 volumes of $10 \%$ trichloroacetic acid solution for 3 minutes. After removal of the supernatant fluid, the residue was re-extracted in the same way. The supernatant fluid corresponds to the non-protein fraction and the residue to the protein fraction. Nitrogen was determined in all fractions by Kjeldahl method.

\section{RESULTS}

The method of muscle fractionation was examined separately from the main experiment. Hind legs' muscle from adult rat was used for the fractionation, after removing the concomitant fats, blood vessels, nervous and connective tissues. As shown in Table II, satisfactory reproducibility of the results was obtained by the method described above.

The results of feeding experiment are shown in Fig. 2. In the experimental feeding period for 4 weeks, the animals of tryptophan-free and protein-free groups lost $19 \%$ and $8 \%$ of their initial body weight respectively, while those of normal group gained 13\%. Daily
TABLE II. AN EXAMINATION OF THE FRACTIONATION METHOD

$$
\text { Fraction }
$$

Non-prot. and

Sarcopl. prot.-N

Myosin-N

Actin-N

Stroma-N

$$
A^{*} \quad B *
$$

$\begin{array}{lll}37.3 \% & 37.1 \% & 37.8 \% \\ 33.4 & 33.3 & 33.4 \\ 11.7 & 11.4 & 11.5 \\ 17.6 & 18.2 & 17.4\end{array}$

* A, B and C are different samples gained from the same muscle. Values are expressed as percentage of total nitrogen.
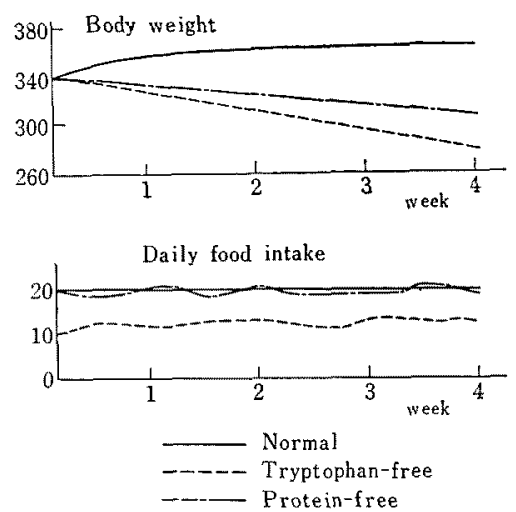

FIG. 2. Body Weight and Food Intake (average of of 4 rats).

food consumption of the tryptophan-free group was a little larger than the half of those of the other two groups.

The amounts of fresh muscle at slaughter were largely decreased in both deficient groups, compared with that of the normal group. (Table III). The ratios of the amount

TABLE III. FEEDING EXPERIMENT

$\begin{array}{ccccc} & & \text { Normal } & \text { Tryptophan-free } & \text { Protein-free } \\ \text { Body weight (initial) } & \mathrm{g} & 333 \pm 26^{*} & 337 \pm 14 & 335 \pm 19 \\ \text { (final) } & \mathrm{g} & 378 \pm 39 & 276 \pm 11 & 307 \pm 20 \\ \text { (difference) } & \% & 12.5 & -18.7 & -8.4 \\ \begin{array}{c}\text { Muscle, fresh weight at slaughter } \\ \text { in final body weight }\end{array} & \mathrm{g} & 74.7 \pm 10.7 & 32.6 \pm 2.3 & 35.4 \pm 5.1 \\ \begin{array}{c}\text { Total nitrogen } \\ \text { mg in l } \mathrm{g} \text { of fresh muscle }\end{array} & & 19.8 & 11.8 & 11.5 \\ \text { in all skeletal muscles } & \mathrm{g} & 34.4 \pm 0.9 & 34.4 \pm 0.5 & 33.2 \pm 0.6 \\ \text { * Mean } \pm \text { Standard deviation. } & & 2575 & 1124 & 1172\end{array}$


Table IV. Composition of Muscle Fractions

$\begin{array}{lrrr}\quad \text { Fraction } & \text { Normal } & \begin{array}{c}\text { Tryptophan- } \\ \text { free }\end{array} & \begin{array}{c}\text { Protein- } \\ \text { free }\end{array} \\ \text { Non-protein-N } & 10.8 \pm 0.1 * & 10.3 \pm 0.1 & 10.8 \pm 0.2 \\ \text { Sarcoplasmic } & 24.0 \pm 0.6 & 22.1 \pm 1.7 & 19.0 \pm 1.1 \\ \quad \text { Protein-N } & 39.9 \pm 0.9 & 40.1 \pm 1.0 & 42.9 \pm 0.4 \\ \text { Myosin-N } & 5.3 \pm 0.5 & 7.8 \pm 0.9 & 5.9 \pm 1.2 \\ \text { Actin-N } & 20.0 \pm 1.4 & 19.8 \pm 0.7 & 21.4 \pm 0.4 \\ \text { Stroma-N } & & \end{array}$

* Values expressed as percentage in total nitrogen.

of fresh muscle to final body weight were also largely decreased in both deficient groups, compared with that in the normal group. Although nitrogen contents of fresh muscle were almost the same in the three groups, those in all skeletal muscle were largely decresaed in the both deficient groups.

The dietary effect on the composition of muscle fractions is shown in Table IV In the tryptophan-free group, the sarcoplasmic protein fraction was decreased, while that of actin fraction was increased. In the proteinfree group, the content of sarcoplasmic protein fraction was decreased, while those of myosin and actin fractions were increased.

\section{DISCUSSION}

At the stage of present study on the relationship between nutritional condition and muscle protein composition, a rough but quantitative fractionation of muscle protein is necessary. According to the methods of several authors, ${ }^{12,13,17 \sim 20 !}$ it is considered best for our purpose to fractionate muscle proteins into four fractions; 1) water-soluble sarcoplasmic proteins containing all glycolytic enzymes, 2) myosin fraction, soluble in the solution of high ionic strength, 3) actin fraction, water-soluble but hardly extractable with water due to its

17) H. H. Weber and K. Meyer, Biochem. Z., 266, 137 (1933).

18) Bate-Smith, Chem. Ind. (London), 53, $351 \mathrm{~T}$ (1934).

19) F. Guba and M. Barany, Nature, 179, 817 (1957).

20) E. Helander, Acta Physiol. Scand., 61 Suppl. 141 (1957).

location in muscle structure and 4) stroma fraction, structural proteins.

Our method shown in Fig. 1 followed chiefly those of Hasselbach and Schneider ${ }^{121}$ and of Robinson. ${ }^{131}$ Pyrophosphate solution extracts myosin fraction quantitatively from muscle by cutting the myosin-actin bond. Actin is extracted enough only after the perfect destruction of muscle structure by homogenization in $0.6 \mathrm{M} \mathrm{KGl}$ solution. Myosin is precipitated by lowereing the ionic strength in solution containing 15\% ethanol and by standing overnight in a cold room. The values shown in Table II coincide with those from rabbit. ${ }^{12,17,18)}$ The reproducibility obtained is considered to be good for our study.

The remarkable loss in the amounts of fresh muscle and of muscle total nitrogen compared with that in body weight, in the both deficient groups, shows that muscle protein is an important protein store for the special use under malnutrition. The larger dietary effect on the body weight and on the amount of fresh muscle of the tryptophan-free group compared with that of the protein-free group indicates not only that a dietary protein of inadequate amino acid composition is not employed effectively for protein synthesis, but that the metabolism of such kind of protein itself is a burden for animal.

As seen in Table IV, different dietary effects were observed on the composition of muscle

Table $V$. DECREASE Rate IN THE AMOUNT OF Fractions of WHOLE SKELETAL MUSCle IN THE EXPERIMENTAL PERIOD FOR 4 WEEKS

Fraction

Total N

Non-protein-N

Sarcoplasmic protein- $\mathrm{N}$

Myosin-N

Actin-N

Stroma-N

Values expressed as percentage of fraction in its initial amount. 
fractions. By supposing that the composition of muscle fractions of the hind legs' muscle represents that of average skeletal muscle and also that the composition of muscle fractions of normal group is constant through the experimental period, the decrease rates in the amount of each fractions of whole skeletal muscle in the experimental period for 4 weeks are shown in Table $\mathrm{V}$.

Between the both deficient groups, different dietary effects on the protein fractions were observed. In the tryptophan-free group, the decrease rates of non-protein nitrogen and sarcoplasmic protein fractions are significantly larger, while that of actin fraction is smaller than that of total nitrogen. In the proteinfree group, the decrease rate of sarcoplasmic protein fraction is larger, while those of myosin, actin and stroma fractions are smaller than that of total nitrogen. Although the dietary effect on the protein fractions is not the same between the both deficient groups, it may be concluded that the non-protein nitrogen and sarcoplasmic protein fractions are relatively sensitive, whereas myosin, actin and stroma fractions are relatively resistible to dietary change. 